\title{
Metabolic Effects of Successful Intraportal Islet Transplantation in Insulin-dependent Diabetes Mellitus
}

\author{
Livio Luzi," Bernhard J. Hering, ${ }^{\ddagger}$ Carlo Socci, ${ }^{*}$ George Raptis, ${ }^{\dagger \dagger}$ Alberto Battezzati, ${ }^{*}$ lleana Terruzzi, ${ }^{*}$ Luca Falqui, ${ }^{\star}$ \\ Heide Brandhorst, ${ }^{\circ}$ Daniel Brandhorst, ${ }^{\circ}$ Enrico Regalia, ${ }^{\S}$ Eugenia Brambilla, Antonio Secchi, ${ }^{*}$ Gianluca Perseghin, ${ }^{\star}$ \\ Paola Maffi, ${ }^{*}$ Elda Bianchi, ${ }^{*}$ Vincenzo Mazzaferro, ${ }^{\S}$ Leandro Gennari, ${ }^{\S}$ Valerio Di Carlo, ${ }^{*}$ Konrad Federlin, ${ }^{\ddagger}$ Guido Pozza, ${ }^{*}$ \\ and Reinhard G. Bretzel ${ }^{\ddagger}$ \\ *Departments of Internal Medicine and Surgery, San Raphael Scientific Institute, University of Milan, Milan, Italy; ${ }^{\ddagger}$ Third Department of \\ Medicine and Policlinic, Justus-Liebig Universität, Gießen, Germany; ${ }^{\S}$ Liver Transplantation Unit, National Cancer Institute, Milan, Italy; \\ and ${ }^{\|}$Department of Medicine, Brigham and Women's Hospital, Harvard Medical School, Boston, Massachusetts 02115
}

\begin{abstract}
The intraportal injection of human pancreatic islets has been indicated as a possible alternative to the pancreas transplant in insulin-dependent diabetic patients. Aim of the present work was to study the effect of intraportal injection of purified human islets on: (a) the basal hepatic glucose production; $(b)$ the whole body glucose homeostasis and insulin action; and $(c)$ the regulation of insulin secretion in insulin-dependent diabetes mellitus patients bearing a kidney transplant. 15 recipients of purified islets from cadaver donors (intraportal injection) were studied by means of the infusion of labeled glucose to quantify the hepatic glucose production. Islet transplanted patients were subdivided in two groups based on graft function and underwent: (a) a 120-min euglycemic insulin infusion $(1 \mathrm{mU} / \mathrm{kg} / \mathrm{min})$ to assess insulin action; $(b)$ a 120-min glucose infusion $(+75$ $\mathrm{mg} / \mathrm{dl}$ ) to study the pattern of insulin secretion. Seven patients with chronic uveitis on the same immunosuppressive therapy as grafted patients, twelve healthy volunteers, and seven insulin-dependent diabetic patients with combined pancreas and kidney transplantation were also studied as control groups. Islet transplanted patients have: $(a)$ a higher basal hepatic glucose production (HGP: $5.1 \pm 1.4 \mathrm{mg} / \mathrm{kg} /$ $\min ; P<0.05$ with respect to all other groups) if without graft function, and a normal HGP $(2.4 \pm 0.2 \mathrm{mg} / \mathrm{kg} / \mathrm{min})$ with a functioning graft; $(b)$ a defective tissue glucose disposal $(3.9 \pm 0.5 \mathrm{mg} / \mathrm{kg} / \mathrm{min}$ in patients without islet function and $5.3 \pm 0.4 \mathrm{mg} / \mathrm{kg} / \mathrm{min}$ in patients with islet function) with respect to normals $(P<0.01$ for both comparisons); $(c)$ a
\end{abstract}

'Dr. George Raptis died in 1994.

Address correspondence to Livio Luzi, M.D., Cellular and Organ Transplant Metabolism Laboratory, Division of EndocrinologyHypertension, Brigham and Women's Hospital and Harvard Medical School, 221 Longwood Avenue, Boston, MA 02115. Phone: 617-7327558; FAX: 617-277-1568.

Received for publication 25 October 1995 and accepted in revised form 18 March 1996.

1. Abbreviations used in this paper: $\mathrm{CON}$, healthy subjects; CU, patients with chronic uveitis; $\mathrm{F}$, islet-transplanted patients with functioning graft; HGP, hepatic glucose production; IDDM, insulindependent diabetes mellitus; MCR, metabolic clearance rate; NF, islet-transplanted patients with nonfunctioning graft; PAN, diabetic patients with intact pancreas transplant.

J. Clin. Invest.

(C) The American Society for Clinical Investigation, Inc.

0021-9738/96/06/2611/08 \$2.00

Volume 97, Number 11, June 1996, 2611-2618 blunted first phase insulin peak and a similar second phase secretion with respect to controls. In conclusion, in spite of the persistence of an abnormal pattern of insulin secretion, successful intraportal islet graft normalizes the basal HGP and improves total tissue glucose disposal in insulin-dependent diabetes mellitus. (J. Clin. Invest. 1996. 97:2611-2618.) Key words: insulin resistance $\bullet$ glucose metabolism $\bullet$ hepatic glucose production $\bullet$ immunosuppressive therapy $\bullet$ islet secretion

\section{Introduction}

Increased hepatic glucose production and insulin resistance are common features of poorly controlled insulin-dependent diabetes mellitus (IDDM) ${ }^{1}$ both before and after the development of chronic renal failure (1-3). Insulin therapy (4) and segmental and whole pancreatic transplantation (5-10) were shown to normalize the glycosylated hemoglobin, the hepatic glucose production, and to ameliorate insulin action in IDDM patients, leading to a near-normalization of glucose homeostasis. Frequent hypoglycemic episodes are a common finding in patients on intensive insulin therapy (4), while peri- and postsurgical morbidity (and also some hypoglycemic episodes) are associated with intact pancreas transplant $(11,12)$. To date, islet transplantation in humans has rarely achieved normoglycemia and suspension of insulin therapy $(5,13)$. Therefore, assessment of the effect of a long-term normalization of glucose concentration on insulin action and glucose homeostasis was not feasible in IDDM patients with an islet graft due to the limited number of patients with functioning grafts available. In the present study, we combined the clinical experience of Milan, Italy and Giessen, Germany to measure hepatic glucose production, insulin action, and insulin secretory pattern in 15 patients with intraportal islet transplantation. This study shows that functioning islet grafts normalize basal hepatic glucose output and ameliorate insulin action notwithstanding the need to administer immunosuppressive drugs.

\section{Methods}

Subjects. 14 insulin-dependent diabetic patients were studied after islet and kidney transplantation. 11 subjects received the islet transplant after the kidney graft (IAK), while three of them received the islets simultaneously with the kidney (SIK). One additional patient received the liver and the islet transplant simultaneously (SIL). We studied a total of 15 patients which allowed us to reach a statistical power of at least $90 \%$ (to detect differences at a 0.05 level) for the parameters under study. No single population (either in Milan or in Giessen) would have been sufficient to achieve a comparable statistical power. Pancreases were obtained from cadaver donors. Islet were separated using an automated procedure, after the injection of Hank's 
Table I. Clinical and Biochemical Parameters of IDDM Patients after Pancreatic Islet Transplantation at the Time of the Present Study Subdivided in Functioning (F) and Nonfunctioning (NF)

\begin{tabular}{|c|c|c|c|c|c|c|c|c|c|c|c|c|c|c|c|c|}
\hline Patients & Sex & SIK/IAK & Age & BMI & $\mathrm{HbA} 1$ & $\begin{array}{l}\text { Insulin } \\
\text { pre Tx }\end{array}$ & Insulin & Prednis. & СуA & Aza & $\begin{array}{l}\text { Days of } \\
\text { transpl. }\end{array}$ & F.P.G. & $\begin{array}{c}\text { Fasting } \\
\text { C-peptide }\end{array}$ & $\begin{array}{c}\text { Serum } \\
\text { creatinine }\end{array}$ & $\begin{array}{l}\text { Diabetes } \\
\text { duration }\end{array}$ & Islet \# \\
\hline & & & $y r$ & & $\%$ & $U / d$ & $U / d$ & $m g / d$ & $m g / d$ & $m g / d$ & & $m g / d l$ & $n g / m l$ & $m g / d l$ & $y r$ & \\
\hline F1 & $\mathrm{F}$ & IAK & 38 & 22 & 6.6 & 46 & 8 & 7.5 & 225 & 0 & 361 & 153 & 2.1 & 4.9 & 33 & 350900 \\
\hline $\mathrm{F} 2$ & $\mathrm{M}$ & IAK & 41 & 21 & 7 & 62 & 6 & 7.5 & 225 & 0 & 180 & 139 & 4.8 & 3.2 & 39 & 770000 \\
\hline F3 & M & IAK & 31 & 20 & 5.8 & 67 & 18 & 15 & 300 & 0 & 134 & 110 & 1.8 & 1.2 & 11 & 1244400 \\
\hline $\mathrm{F} 4$ & $\mathrm{M}$ & SIL & 48 & 22 & 6 & 40 & 0 & 10 & 800 & 0 & 67 & 113 & 2.1 & 1.4 & 1 & 820000 \\
\hline F5 & $\mathrm{F}$ & IAK & 40 & 22 & 5 & 32 & 5 & 5 & 280 & 56 & 399 & 98 & 2.05 & 0.9 & 36 & 482150 \\
\hline F6 & M & SIK & 48 & 20 & 7.2 & 60 & 0 & 10 & 270 & 54 & 144 & 101 & 2.96 & 1 & 30 & 910375 \\
\hline F7 & $\mathrm{F}$ & IAK & 53 & 23 & 5.6 & 49 & 0 & 7 & 265 & 53 & 230 & 102 & 1.99 & 1 & 37 & 612500 \\
\hline F8 & M & IAK & 50 & 23 & 6.5 & 40 & 0 & 10 & 275 & 55 & 25 & 120 & 4.6 & 1.3 & 35 & 592500 \\
\hline Mean & & & 44 & 21.6 & 6.2 & 49.5 & 4.6 & 9 & 330 & 27 & 192 & 117 & 2.8 & 1.8 & 28 & 722853 \\
\hline SE & & & 2.6 & 0.42 & 0.26 & 4.3 & 2.2 & 1.1 & 68 & 10 & 47 & 7 & 0.4 & 0.5 & 5 & 98587 \\
\hline NF1 & M & IAK & 30 & 23 & 6.5 & 40 & 60 & 30 & 400 & 0 & 30 & 176 & 0.02 & 1.8 & 32 & 521000 \\
\hline NF2 & $\mathrm{M}$ & IAK & 43 & 21 & 5.2 & 30 & 55 & 10 & 300 & 50 & 71 & 103 & 1.4 & 1.5 & 35 & 1060000 \\
\hline NF3 & M & IAK & 43 & 23 & 6.5 & 68 & 36 & 25 & 250 & 0 & 62 & 362 & 0.23 & 1.2 & 43 & 583500 \\
\hline NF4 & M & IAK & 49 & 27 & 7.6 & 42 & 68 & 25 & 200 & 0 & 58 & 420 & 0.14 & 2 & 44 & 597900 \\
\hline NF5 & M & IAK & 39 & 22 & 6.5 & 48 & 45 & 4 & 300 & 60 & 423 & 147 & 0.02 & 0.7 & 27 & 1294125 \\
\hline NF6 & M & SIK & 41 & 24 & 7.1 & 40 & 40 & 10 & 270 & 54 & 714 & 162 & 0.42 & 1.5 & 36 & 248500 \\
\hline NF7 & $\mathrm{M}$ & SIK & 38 & 23 & 9.1 & 60 & 90 & 10 & 260 & 52 & 132 & 222 & 0.04 & 0.8 & 22 & 180000 \\
\hline Mean & & & 40 & 23.2 & 6.9 & 53 & 56 & 16.2 & 283 & 31 & 213 & 227 & 0.32 & 1.4 & 34 & 640717 \\
\hline SE & & & 2.2 & 0.71 & 0.45 & 7.3 & 7 & 3.8 & 23 & 11 & 99 & 45 & 0.18 & 0.18 & 3 & 153396 \\
\hline$P$ & & & NS & 0.052 & NS & NS & $<0.0001$ & 0.072 & NS & NS & NS & 0.021 & $<0.0001$ & NS & NS & NS \\
\hline
\end{tabular}

Aza, azathioprine; SIK, simultaneous islet and kidney transplant; IAK, islet after kidney transplant; SIL, simultaneous islet and liver transplant; FPG, fasting plasma glucose.

solution containing Collagenase (Boehringher Mannheim Biochemicals, Indianapolis, IN). Islets were purified and separated from the exocrine pancreas by centrifugation on density gradients (Ficoll, DL400; Sigma Chemical Co., St. Louis, MO). In all cases purified islets were injected into the liver via the portal vein. The patient's clinical and laboratory data are represented in Table I. All biochemical and clinical parameters presented in the table were stable during the $4 \mathrm{wk}$ preceding this investigational protocol.

We subdivided the 15 patients with islet graft into two subgroups on the basis of the success of the transplant: F, 8 patients with, and NF, 7 patients without function. Four major criteria were used: $(a)$ capacity of the graft to secrete insulin (using the c-peptide concentration as a parameter); (b) fasting plasma glucose; $(c)$ percentage of glycosylated hemoglobin after insulin suspension (or on low-dose insulin treatment) for at least $4 \mathrm{wk}$; and $(d)$ daily insulin dose. Obviously, for each of the four parameters chosen as indexes of function, it was necessary to determine a cut-off point between functioning and nonfunctioning grafts. This was a critical issue for the present work. Using the most conservative criteria (1. c-peptide concentration $>1.8 \mathrm{ng} / \mathrm{ml} ; 2$. F.P.G. $<140 \mathrm{mg} / \mathrm{dl} ; 3$. glycosylated hemoglobin $<6.5 \% ; 4$. patient off insulin [or injecting 5-8 U/d] for at least 4 wk, only 3 of 15 patients could be considered to have graft function at the time of study (patients F4, F7, and F8, Table I). By allowing one or two of the four parameters to escape the set limit (with the exception of c-peptide, considered fixed), the number of patients considered to have function at the time of the study (and at least for the preceding $4 \mathrm{wk}$ ) increased to eight (patients F1-F8; Table I). We have used the less stringent criterion to analyze the data for the following reasons: $(a)$ using both criteria, the fasting c-peptide concentration was $\sim 2 \mathrm{ng} / \mathrm{ml} ;(b)$ a small amount of daily insulin was often injected discretionally by the patients still on insulin, to optimize the glycemic control; and (c) finally, re-analyzing the data using the most strict criterion (e.g., comparing three patients with function with the patients without function) the major conclusions of the present work do not change. Interestingly, two patients (F3 and NF2) had partial function (fasting c-peptide of 1.8 and $1.4 \mathrm{ng} / \mathrm{ml}$, respectively). In contrast, the remaining six patients were nearly without function.

We also studied a group of seven nondiabetic patients with chronic uveitis $(\mathrm{CU})$ on the same immunosuppressive regimen as islet-transplanted patients to define the effect of chronic immunosuppression per se on the parameters under evaluation. Seven patients (PAN) with intact pancreas and kidney transplantation (standard transplant therapy for IDDM associated with uremia) were studied using the hyperglycemic clamp technique to compare the regulation of insulin secretion of intrahepatic islets with that of an intact pancreas transplant in IDDM. Since the population of diabetic patients was approximately half Italian and half German, we also studied 12 healthy volunteers (CON, 6 studied in Giessen, Germany and 6 studied in Milan, Italy), to control for possible ethnic, dietary, and environmental differences (Table II).

Table II. Clinical and Biochemical Parameters of Patients with Chronic Uveitis (CU), Normal Subjects (CON), and Pancreas-transplanted Patients (PAN)

\begin{tabular}{lccc}
\hline & & & \\
& $\begin{array}{c}\text { Chronic uveitis } \\
(\mathrm{CU})\end{array}$ & $\begin{array}{c}\text { Pormal subjects } \\
(\mathrm{CON})\end{array}$ & $\begin{array}{c}\text { Panseas } \\
\text { transplanted } \\
\text { patients (PAN) }\end{array}$ \\
\hline Age (yr) & $40 \pm 2$ & $38 \pm 5$ & $36 \pm 3$ \\
Sex (males/females) & $5 / 2$ & $9 / 3$ & $5 / 2$ \\
BMI $\left(\mathrm{kg} / \mathrm{m}^{2}\right)$ & $22.9 \pm 2.1$ & $23.0 \pm 2.0$ & $22.1 \pm 1.9$ \\
HbA1 $(\%)$ & $5.8 \pm 0.4$ & $5.6 \pm 0.3$ & $6.0 \pm 0.4$ \\
Prednisone (mg/d) & $12 \pm 3$ & - & $9 \pm 3$ \\
CyA (mg/kg/d) & $5 \pm 1$ & - & $6 \pm 1$ \\
Azathioprine (mg/kg/d) & - & - & $1.1 \pm 0.3$ \\
Serum creatinine (mg/ml) & $1.1 \pm 0.2$ & $0.9 \pm 0.2$ & $1.2 \pm 0.3$
\end{tabular}




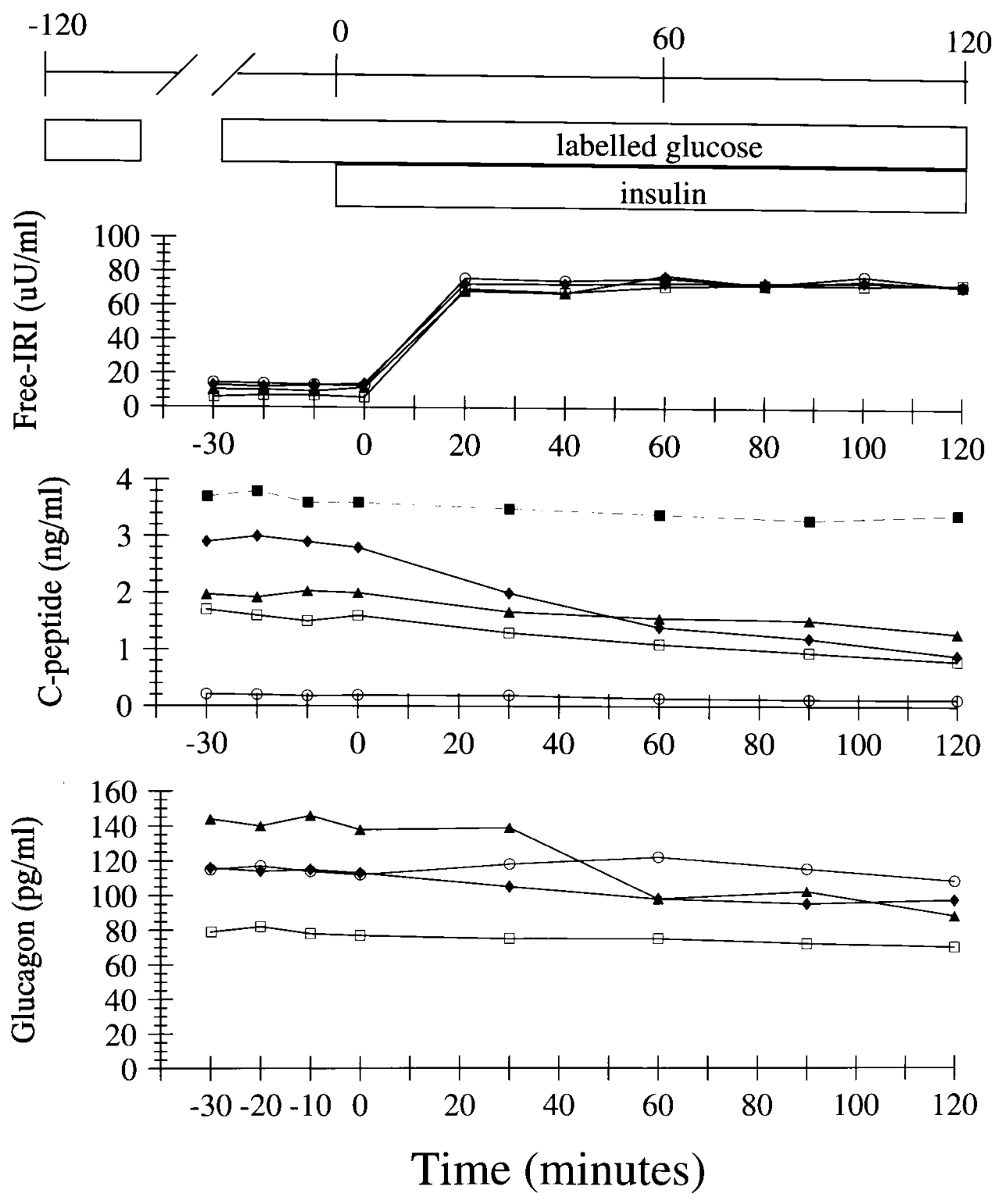

Figure 1. This figure depicts the experimental protocol of Study 1 $(1 \mathrm{mU} / \mathrm{kg} / \mathrm{min}$ insulin infusion, maintaining euglycemia). The steady state post-absorptive concentrations as well as the timedependent variation of free insulin, c-peptide and glucagon during the 120-min insulin infusion are represented for F (islet transplanted patients with function, $\boldsymbol{\Delta}$ ), NF (islet transplanted patients without function, $\bigcirc$ ), $\mathrm{CU}$ (patients with chronic uveitis, $\bullet$ ), and CON (normal subjects, $\square$ ). $\mathbf{\square}$, represents the c-peptide concentration of pancreas transplanted patients during insulin infusion (17).

Experimental protocol. (Figs. 1 and 2). A similar experimental protocol was performed in the metabolic units of San Raphael Hospital in Milan, Italy and the Third Department of Medicine and Policlinic at the Justus-Liebig-Universität in Giessen, Germany. The experimental protocol was approved by the Ethical Committees of both the San Raphael Hospital and the Justus-Liebig-Universität. All the experiments were performed by Dr. Livio Luzi (both in Italy and in Germany) to guarantee uniformity of experimental techniques and comparability of data analysis. Therefore, the in vivo experimental techniques, the laboratory techniques, and the analysis of data were identical for all subjects.

All study subjects were admitted to the ward the night before the study at 5:00 p.m. They were maintained on a diet of at least $250 \mathrm{~g}$ of carbohydrates and $70-80 \mathrm{~g}$ of proteins per $\mathrm{d}$ for the $2 \mathrm{wk}$ preceding the study. In the four islet transplanted patients receiving some units of insulin, the intermediate-acting insulin was withdrawn at least $36 \mathrm{~h}$ before the study, and no regular insulin was injected after 1:00 p.m. the day before the study. At 7:00 a.m. on the day of the study, two plastic catheters were placed into forearm veins for the infusion of study solutions and arterialized blood drawing as previously described (10). Due to specific radioprotection guidelines of the Federal Republic of Germany all patients studied in Giessen (F1, F2, F3, NF1,
NF2, NF3, NF4) received a $\left[6,6-\mathrm{d}_{2}\right]$-glucose to quantify whole-body glucose metabolism. $\left[3-{ }^{3} \mathrm{H}\right]$-glucose infusion was performed as described (10) in all patients studied in Milan (F4, F5, F6, F7, F8, NF5, NF6, NF7). Study 1: (Fig. 1). After a tracer equilibration period adequate to achieve tracer's steady state in plasma (a minimum of 90-120 min), all study subjects belonging to groups F, NF, CU, and CON underwent a euglycemic hyperinsulinemic clamp $(1 \mathrm{mU} / \mathrm{kg} / \mathrm{min})$, lasting an additional $120 \mathrm{~min}$. In groups $\mathrm{F}, \mathrm{CU}$, and $\mathrm{CON}$, the plasma glucose concentration was maintained at euglycemia $(\sim 100 \mathrm{mg} / \mathrm{dl})$, while in group NF the plasma glucose was clamped at $\sim 180 \mathrm{mg} / \mathrm{dl}$. Study 2 : (Fig. 2). Four patients with functioning islet transplantation (F), all the patients with chronic uveitis $(\mathrm{CU})$, the normal controls $(\mathrm{CON})$, and the diabetic patients with intact pancreas transplantation (PAN) received a $+75 \mathrm{mg} / \mathrm{dl}$ hyperglycemic clamp to stimulate insulin secretion (Fig. 2). The desired glucose level during the hyperglycemic clamp was chosen to match the post-prandial glucose concentration $(\sim 180 \mathrm{mg} / \mathrm{dl})$.

Plasma glucose, plasma tritiated glucose specific activities, and plasma deuterated glucose enrichments were assessed every 10-30 min in the last hour of the basal equilibration period and during the 120 min of the euglycemic study. During the euglycemic clamp, the plasma free insulin, plasma c-peptide, and plasma glucagon were 

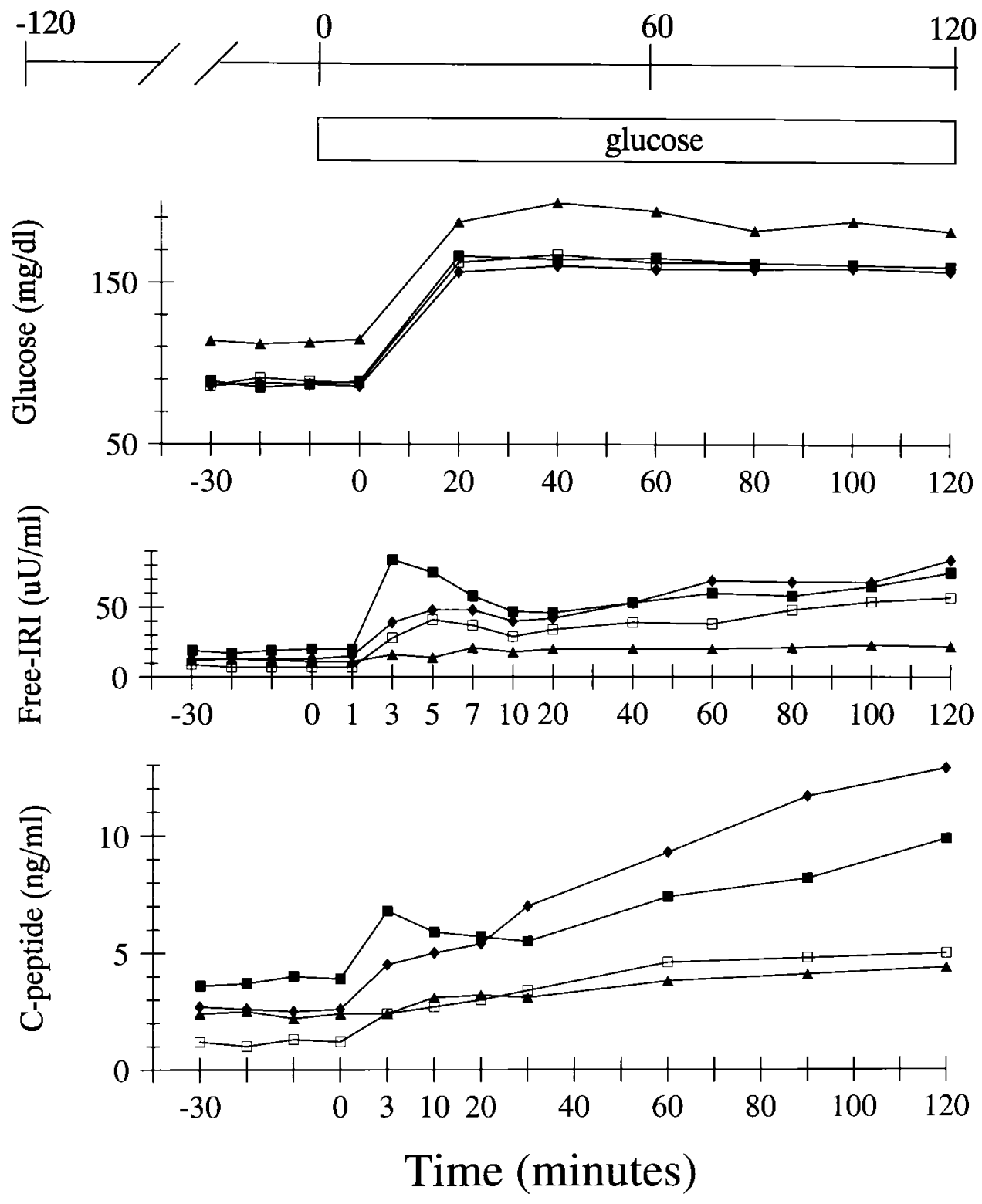

Figure 2. This figure depicts the experimental protocol of Study 2 (+75 mg/dl hyperglycemic clamp). The steady state post-absorptive concentrations as well as the timedependent variation of glucose, free insulin, and c-peptide during the 120 min glucose infusion are represented for $\mathrm{F}(\boldsymbol{\Delta}), \mathrm{CU}(\diamond)$, $\mathrm{CON}(\square)$, and PAN (匹).

measured every 10-30 min in the last hour of the basal period and every 10 min throughout the study as previously described (Fig. 1 and Table III) (10). Plasma glucose, free insulin, and c-peptide concentrations were measured every minute in the initial $15 \mathrm{~min}$ of the hyperglycemic clamp to detect the first phase insulin release (14) and every 10-30 min thereafter (Fig. 2).

Free fatty acids (FFA) and lactate were measured in plasma every $20 \mathrm{~min}$ in the last hour of the basal state and throughout the studies (Table IV).

Analytical determinations and calculations. Plasma glucose was measured bedside with a Beckman glucose analyzer (10), free insulin was measured by means of a RIA Incstar (Stillwater, Minnesota) (10), c-peptide was measured by means of a RIA using a double-antibody (10), and glucagon, free fatty acids, lactate, tritiated glucose specific activity were measured as previously described (10). Deuterated glucose enrichments were measured by means of gas-chromatography/mass spectrometry with a technique using a derivatization of the sample by means of boroacetylation (15). Hepatic glucose production and peripheral glucose disposal were assessed as described previously (10). The metabolic clearance rate of glucose (MCR) was calculated by dividing the tissue glucose disposal by the corresponding plasma glucose concentration in all study groups $(1,10)$.
Statistical analysis was performed using the CSS software (Complete Statistical System; StatSoft Inc.). ANOVA with one between groups factor and one repeated measures factor was used. Comparisons between groups were performed by the Scheffe test. When only two groups were compared, the Student's $t$ test was used (16).

\section{Results}

Plasma glucose, insulin, c-peptide, and glucagon concentrations in the basal state, during insulin infusion and during glucose infusion in F, NF, CU,CON, and PAN. (Table III and Figs. 1 and 2). In the post-absorptive state, the plasma glucose concentration was higher in NF $(249 \pm 45 \mathrm{mg} / \mathrm{dl})$ with respect to $\mathrm{F}$ (114 $\pm 9 \mathrm{mg} / \mathrm{dl}, P<0.01), \mathrm{CU}(87 \pm 4, P<0.001)$ and CON (88 $\pm 2, P<0.001)$. During the insulin clamp the glucose concentration was maintained constant at $98 \pm 3,87 \pm 2$, and $92 \pm 3$ $\mathrm{mg} / \mathrm{dl}$ in $\mathrm{F}, \mathrm{CU}$, and CON, respectively. In contrast, in NF, the plasma glucose concentration was left to decrease to $\sim 180$ $\mathrm{mg} / \mathrm{dl}$, level at which it was clamped for an additional 60-90 min. During the hyperglycemic clamp the plasma glucose con- 
Table III. Glucose, Free Insulin, c-peptide, and Glucagon Plasma Concentrations in the Last Hour of the Basal State and in the Last Hour of the Euglycemic Insulin Clamp in IDDM Patients with Functioning Islet Graft (F), IDDM with Graft without Function (NF), Patients with Chronic Uveitis (CU), and Healthy Volunteers (CON)

\begin{tabular}{|c|c|c|c|c|c|}
\hline & & $\mathrm{F}$ & $\mathrm{NF}$ & $\mathrm{CU}$ & $\mathrm{CON}$ \\
\hline \multicolumn{6}{|l|}{ Glucose } \\
\hline \multirow[t]{2}{*}{$(\mathrm{mg} / \mathrm{dl})$} & Basal & $114 \pm 9^{\S}$ & $249 \pm 45^{*}$ & $87 \pm 4$ & $88 \pm 2$ \\
\hline & Insulin & $98 \pm 3^{\S}$ & $167 \pm 35^{\|}$ & $87 \pm 2$ & $92 \pm 3$ \\
\hline \multicolumn{6}{|l|}{ Free-IRI } \\
\hline \multirow[t]{2}{*}{$(\mathrm{uU} / \mathrm{ml})$} & Basal & $10 \pm 2^{\|}$ & $14 \pm 5$ & $13 \pm 3^{\|}$ & $6 \pm 1$ \\
\hline & Insulin & $74 \pm 4$ & $77 \pm 9$ & $75 \pm 3$ & $72 \pm 3$ \\
\hline \multicolumn{6}{|l|}{ C-peptide } \\
\hline \multirow[t]{2}{*}{ (ng/ml) } & Basal & $1.9 \pm 0.6$ & $0.2 \pm 0.02 * *$ & $2.9 \pm 0.3$ & $1.7 \pm 0.3$ \\
\hline & Insulin & $1.1 \pm 0.3$ & $0.3 \pm 0.1^{*}$ & $0.9 \pm 0.4$ & $0.79 \pm 0.09$ \\
\hline \multicolumn{6}{|l|}{ Glucagon } \\
\hline \multirow[t]{2}{*}{$(\mathrm{pg} / \mathrm{ml})$} & Basal & $141 \pm 35^{\ddagger}$ & $115 \pm 27^{\ddagger}$ & $116 \pm 21^{\ddagger}$ & $79 \pm 7$ \\
\hline & Insulin & $95 \pm 9$ & $108 \pm 22$ & $97 \pm 9$ & $70 \pm 8$ \\
\hline
\end{tabular}

*Indicates $P<0.01$ with respect to the basal; *indicates $P<0.05$ with respect to $\mathrm{CON}$; ${ }^{8}$ indicates $P<0.01$ with respect to NF; $\|_{\text {indicates } P<}$ 0.01 with respect to $\mathrm{CON}$; **indicates $P<0.001$ with respect to $\mathrm{CON}$.

centration was increased by $70-80 \mathrm{mg} / \mathrm{dl}$ above the postabsorptive level by means of a $20 \%$ glucose infusion (185 \pm 7 , $160 \pm 9,162 \pm 9$, and $162 \pm 7 \mathrm{mg} / \mathrm{dl}$ in F, CU, CON, and PAN, respectively). Patients with nonfunctioning islet graft (NF) did not receive the hyperglycemic stimulus.

The fasting plasma free insulin concentration was not statistically different in F, NF, and $\mathrm{CU}(10 \pm 2,14 \pm 5$, and $13 \pm 3$ $\mu \mathrm{U} / \mathrm{ml}$, respectively). The free insulin concentration was significantly higher in F than in CON $(10 \pm 2$ vs. $6 \pm 1 \mu \mathrm{U} / \mathrm{ml}, P<$ 0.05). During euglycemic hyperinsulinemia the insulin concentration at plateau was not statistically different among the four groups $(74 \pm 4,77 \pm 9,75 \pm 3$, and $72 \pm 3 \mu \mathrm{U} / \mathrm{ml}$ in $\mathrm{F}, \mathrm{NF}, \mathrm{CU}$, and $\mathrm{CON}$, respectively). During the hyperglycemic clamp, the peak of first phase insulin release was impaired in F (1-10 min, $16 \pm 2 \mu \mathrm{U} / \mathrm{ml})$, with respect to $\mathrm{CU}(33 \pm 9 ; P<0.05), \mathrm{CON}$ $(25 \pm 3 ; P<0.05)$, and PAN $(56 \pm 15 \mu \mathrm{U} / \mathrm{ml} ; P<0.05)$. The second phase insulin release (20-120 $\mathrm{min}$ of the hyperglycemic clamp) was impaired in $\mathrm{F}(21 \pm 5 \mu \mathrm{U} / \mathrm{ml})$ with respect to $\mathrm{CU}$ $(58 \pm 12 ; P<0.05$ with respect to $\mathrm{F}), \mathrm{CON}(45 \pm 8 ; P<0.05)$, and PAN $(56 \pm 10 ; P<0.01)$.

The post-absorptive c-peptide concentration was higher in PAN $(3.7 \pm 0.1 \mathrm{ng} / \mathrm{ml})$, with respect to F $(1.9 \pm 0.6 \mathrm{ng} / \mathrm{ml} ; P<$ 0.05 with respect to PAN), CU $(2.9 \pm 0.3 \mathrm{ng} / \mathrm{ml} ; P<0.05)$, and CON (1.7 $\pm 0.3 ; P<0.01)$. Islet transplanted patients with no function had a nearly absent basal c-peptide secretion $(0.2 \pm 0.02$ $\mathrm{ng} / \mathrm{ml}$ ). During euglycemic hyperinsulinemia, the inhibition of c-peptide concentration was not significantly different between $\mathrm{F}$ and $\mathrm{CON}$ (42 and $50 \%$ of the basal, respectively; Table III). F showed a lower decrement of c-peptide concentration with respect to $\mathrm{CU}(P<0.05)$, and the inhibition of c-peptide concentration during insulin infusion was lacking in PAN (Fig. 1). The data showing the lack of c-peptide inhibition during euglycemic hyperinsulinemia were partially previously reported (17). The increment of c-peptide above basal during the hyperglycemic clamp was significantly defective in F with respect to all groups. CU $(4.2 \pm 0.8 \mathrm{ng} / \mathrm{ml} ; P<0.05$ with
Table IV. HGP, MCR, and Tissue Glucose Disposal (M) in the Last Hour of the Basal State (HGP and MCR), and during the Last Hour of the Euglycemic Insulin Clamp (HGP, MCR, and $M)$ in IDDM Patients with a Functioning Graft $(F)$, in IDDM Patients with a Graft without Function (NF), in Patients with $C U$ and in Healthy Subjects (CON)

\begin{tabular}{lcccc}
\hline & $\mathrm{F}$ & $\mathrm{NF}$ & $\mathrm{CU}$ & $\mathrm{CON}$ \\
\hline $\mathrm{HGP}(\mathrm{mg} / \mathrm{kg} / \mathrm{min})$ & & & & \\
$\quad$ Basal & $2.4 \pm 0.2^{\ddagger}$ & $5.1 \pm 1.4^{\S}$ & $2.3 \pm 0.3^{\ddagger}$ & $2.2 \pm 0.2$ \\
$\quad$ Insulin & $0.5 \pm 0.1^{*}$ & $1.3 \pm 0.2^{\S}$ & $0.2 \pm 0.1^{*}$ & $0.2 \pm 0.1^{*}$ \\
$\mathrm{MCR}(\mathrm{ml} / \mathrm{kg} / \mathrm{min})$ & & & & \\
$\quad$ Basal & $2.12 \pm 0.16$ & $1.64 \pm 0.22^{\|}$ & $2.58 \pm 0.20$ & $2.21 \pm 0.16$ \\
$\quad$ Insulin & $4.81 \pm 0.80^{*}$ & $2.33 \pm 0.36^{\S \pi}$ & $4.73 \pm 0.32^{*}$ & $8.01 \pm 0.56^{*}$ \\
M (mg/kg/min) & & & & \\
$\quad$ Insulin & $5.3 \pm 0.6^{\ddagger}$ & $3.9 \pm 0.5^{\S}$ & $4.1 \pm 0.4^{\S}$ & $7.4 \pm 0.3$ \\
& & & & \\
\hline
\end{tabular}

*Indicates $P<0.01$ with respect to the basal; *indicates $P<0.05$ with respect to NF; ${ }^{\S}$ indicates $P<0.01$ with respect to $\mathrm{CON}$; " indicates $P<$ 0.05 with respect to $\mathrm{F}$ and $\mathrm{CU}$; ${ }^{\mathrm{I}}$ indicates $P<0.01$ with respect to $\mathrm{F}$ and CU.

respect to $\mathrm{F}$ and $\mathrm{CON})$ and $\mathrm{PAN}(5.9 \pm 0.9 \mathrm{ng} / \mathrm{ml} ; P<0.01$ with respect to $\mathrm{F}$ and $\mathrm{CON}$ ) showed a higher early peak of insulin secretion than F $(2.8 \pm 0.5)$ and CON $(2.1 \pm 0.5)$. The second phase c-peptide release (20-120 minutes) did not differ between F $(3.7 \pm 1.0 \mathrm{ng} / \mathrm{ml})$ and $\mathrm{CON}(3.6 \pm 0.5 \mathrm{ng} / \mathrm{ml} ; P=\mathrm{NS}$ with respect to $F)$. The second phase c-peptide plateaus of $F$ $(3.7 \pm 1.0 \mathrm{ng} / \mathrm{ml})$ and CON $(3.6 \pm 0.5)$ were significantly lower than CU $(9.2 \pm 1.8 \mathrm{ng} / \mathrm{ml} ; P<0.01)$ and PAN $(7.5 \pm 1.1 \mathrm{ng} / \mathrm{ml}$; $P<0.01)$.

The post-absorptive glucagon concentration was higher in F $(141 \pm 35 \mathrm{pg} / \mathrm{ml} ; P<0.05), \mathrm{NF}(115 \pm 27 \mathrm{pg} / \mathrm{ml} ; P<0.05), \mathrm{CU}$ $(116 \pm 21 \mathrm{pg} / \mathrm{ml} ; P<0.05)$, and PAN $(135 \pm 17 \mathrm{pg} / \mathrm{ml} ; P<0.01)$ with respect to healthy subjects $(\mathrm{CON}, 79 \pm 7 \mathrm{pg} / \mathrm{ml})$. During euglycemic hyperinsulinemia the plasma glucagon concentration was inhibited in F $(141 \pm 13$ to $95 \pm 9 \mathrm{pg} / \mathrm{ml} ; P<0.01$ with respect to basal) while showing a trend toward inhibition in $\mathrm{CU}(116 \pm 21$ to $97 \pm 9 \mathrm{pg} / \mathrm{ml} ; P=\mathrm{NS})$ and CON (79 \pm 7 to $70 \pm 8$ $\mathrm{pg} / \mathrm{ml} ; P=\mathrm{NS}$ ). In contrast, in NF (IDDM patients with nonfunctioning islets) the glucagon concentration did not change from the basal state during insulin infusion $(115 \pm 27$ to $108 \pm 22$ $\mathrm{pg} / \mathrm{ml} ; P=\mathrm{NS}$ ). During hyperglycemia no significant variation of glucagon concentration was observed in the groups $\mathrm{F}, \mathrm{CU}$, $\mathrm{CON}$, and PAN with respect to the basal condition.

Free fatty acids and lactate concentrations in the basal state, during insulin infusion in $F, N F, C U, C O N$, and PAN. Basal free fatty acid concentration was similar in patients with islet transplantation ( $\mathrm{F}$ and NF, $798 \pm 150$ and $596 \pm 233 \mu \mathrm{mol} / \mathrm{liter}$, respectively), in patients with chronic uveitis (CU, 757 \pm 75

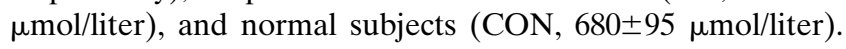
During euglycemic hyperinsulinemia the inhibition of free fatty acid concentration was not statistically different in IDDM patients with nonfunctioning islets (NF, 596 \pm 233 to $239 \pm 29 \mu \mathrm{mol} /$ liter) with respect to $\mathrm{F}(798 \pm 150$ to $89 \pm 7 \mu \mathrm{mol} / \mathrm{liter}), \mathrm{CU}$

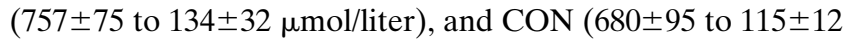
$\mu \mathrm{mol} / \mathrm{liter})$.

Post-absorptive blood lactate concentration was similar in patients with functioning $(\mathrm{F}, 0.60 \pm 0.20 \mathrm{mmol} / \mathrm{liter})$ and nonfunctioning islet transplant ( $\mathrm{NF}, 0.93 \pm 0.44 \mathrm{mmol} / \mathrm{liter})$, in patients with chronic uveitis (CU, $0.93 \pm 0.33 \mathrm{mmol} / \mathrm{liter})$, and in 


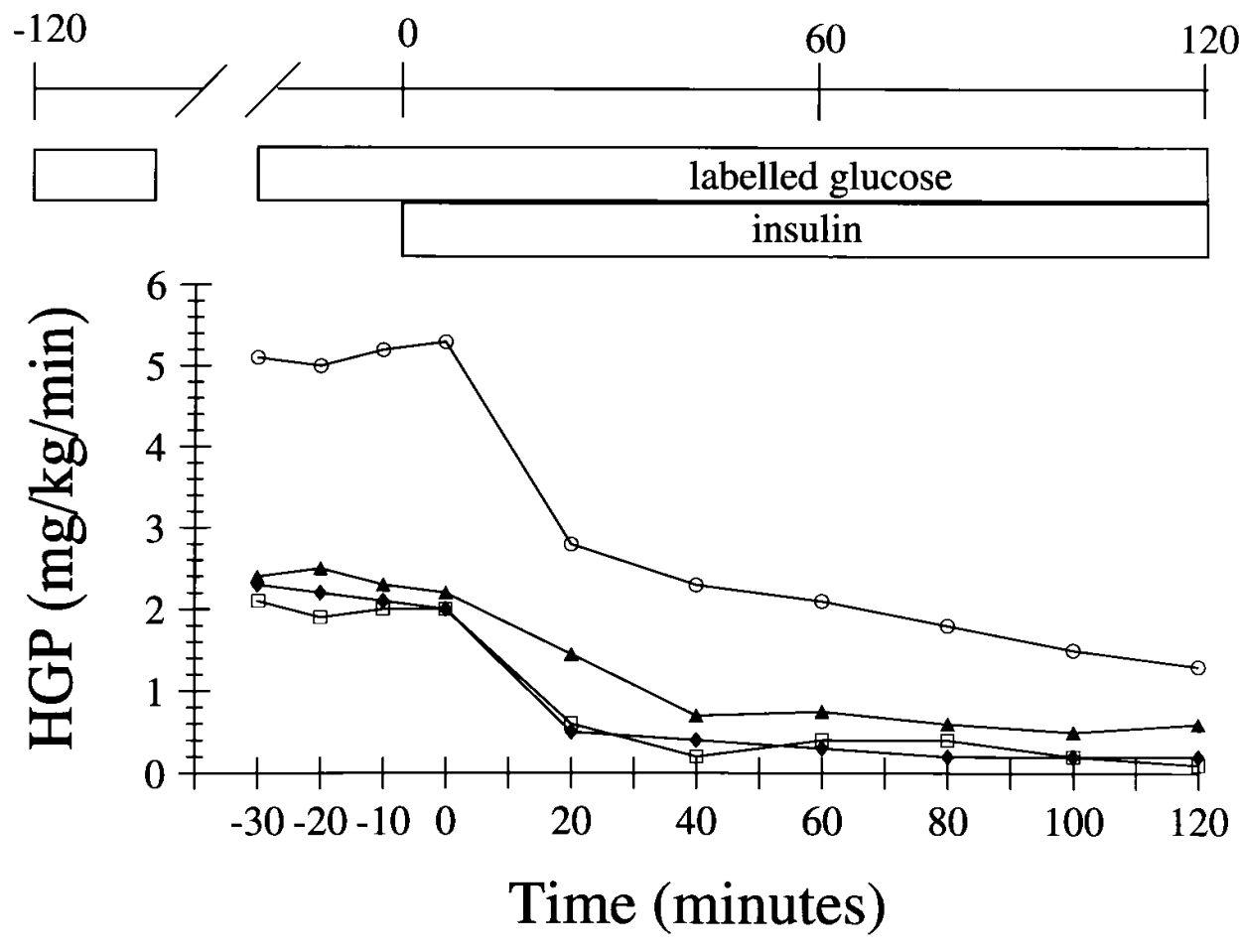

Figure 3. The figure represents the kinetics of inhibition of hepatic glucose production in $\mathrm{F}(\triangle)$, NF $(\bigcirc)$, $\mathrm{CU}(\diamond)$, and CON $(\square)$ during insulin infusion. NF show a markedly increased basal hepatic glucose production, which remains persistently high during insulin infusion. Basal and insulin-inhibited hepatic glucose production appears to be nor$\mathrm{mal}$ in $\mathrm{F}$.

normal subjects (CON, $0.68 \pm 0.36 \mathrm{mmol} / \mathrm{liter})$. During euglycemic hyperinsulinemia blood lactate concentration increased in all groups with respect to the basal (F: from $0.60 \pm 0.20$ to $1.17 \pm 0.23 \mathrm{mmol} / \mathrm{liter}, P<0.05$ with respect to the basal; NF: from $0.93 \pm 0.44$ to $1.19 \pm 0.32 \mathrm{mmol} / \mathrm{liter}, P=\mathrm{NS}$; CU: from $0.93 \pm 0.33$ to $1.05 \pm 0.20 \mathrm{mmol} / \mathrm{liter}, P=\mathrm{NS}$; CON: from $0.68 \pm 0.36$ to $1.03 \pm 0.25 \mathrm{mmol} /$ liter; $P<0.05$ ).

Hepatic glucose production and peripheral glucose disposal, in the basal state and during insulin infusion (Table IV, Fig. 3). Post-absorptive hepatic glucose output was higher in patients with nonfunctioning islets $(5.1 \pm 1.4 \mathrm{mg} / \mathrm{kg} / \mathrm{min})$ with respect to patients with functioning graft $(2.4 \pm 0.2 ; P<0.05)$, patients with chronic uveitis $(2.3 \pm 0.3 ; P<0.05)$, and healthy subjects $(2.2 \pm 0.2 ; P<0.01)$. During the second hour of the euglycemic hyperinsulinemic clamp (insulin concentration $\sim 70 \mu \mathrm{U} / \mathrm{ml}$ ) the hepatic glucose production showed a similar decrement in $\mathrm{F}$ (from $2.4 \pm 0.2$ to $0.5 \pm 0.1 \mathrm{mg} / \mathrm{kg} / \mathrm{min}$ ), NF (from $5.1 \pm 1.4$ to $1.3 \pm 0.2$ ), $\mathrm{CU}$ (from $2.3 \pm 0.3$ to $0.2 \pm 0.1$ ), and $\mathrm{CON}$ (from $2.2 \pm 0.2$ to $0.2 \pm 0.1$ ). IDDM patients with no function (NF) showed a persistently high hepatic glucose output both during the first $(1.6 \pm 1.0 \mathrm{mg} / \mathrm{kg} / \mathrm{min})$ and the second $(1.3 \pm 0.2 \mathrm{mg} / \mathrm{kg} /$ min) hour of hyperinsulinemia.

In the post-absorptive state, near steady state conditions of glucose homeostasis do exist. Therefore, the total body glucose uptake equals the hepatic glucose output. This value accounts for the amount of glucose entering the utilizing tissues (tissue glucose disposal) and for the urinary glucose losses (1). The tissue glucose disposal calculated during the second hour of the euglycemic insulin clamp was impaired in $\mathrm{F}(5.3 \pm 0.6 \mathrm{mg} /$ $\mathrm{kg} / \mathrm{min} ; P<0.01), \mathrm{NF}(3.9 \pm 0.5 \mathrm{mg} / \mathrm{kg} / \mathrm{min} ; P<0.01)$, and $\mathrm{CU}$ $(4.1 \pm 0.4 \mathrm{mg} / \mathrm{kg} / \mathrm{min} ; P<0.01)$ with respect to healthy subjects $(7.4 \pm 0.3 \mathrm{mg} / \mathrm{kg} / \mathrm{min})$. F had a peripheral glucose disposal significantly higher than NF $(P<0.05)$.

Metabolic clearance rate (MCR) of glucose (Table IV). The tissue glucose disposal is markedly influenced by the ambient glucose concentration. In fact, a high glucose level may per se enhance the tissue glucose utilization independently of the insulin concentration. Therefore, the $M$ value for NF (in the presence of hyperglycemia) is overestimated. A more appropriate presentation of the data is achieved by factoring out the glucose level, that is, by dividing the tissue glucose disposal by the corresponding glucose concentration (glucose clearance). In the basal state, the MCR of glucose of NF $(1.64 \pm 0.22$ $\mathrm{ml} / \mathrm{kg} / \mathrm{min})$ was significantly lower $(P<0.05)$ than $\mathrm{F}(2.12 \pm 0.16)$, CU (2.58 \pm 0.20$)$, and CON (2.21 \pm 0.16$)$. Similarly, during insulin infusion, the increment of MCR above the basal value was defective in NF $(2.33 \pm 0.36 \mathrm{ml} / \mathrm{kg} / \mathrm{min})$ with respect to $\mathrm{F}$ (4.91 $\pm 0.80, P<0.05)$, CU $(4.34 \pm 0.32, P<0.05)$, and CON $(8.01 \pm 0.56, P<0.001)$.

\section{Discussion}

The intraportal injection of purified human islets under angiographic guide is a fairly noninvasive procedure which entails the injection of $\sim 1 \mathrm{ml}$ of islet tissue into the hepatic parenchyma. Metabolic studies in islet transplanted patients have been limited by the scarce number of patients transplanted successfully in any single center worldwide. Therefore, the opportunity to have eight patients with functioning islet grafts for a minimum of $4 \mathrm{wk}$ is rather unique. It is important to note that intrahepatically injected islets can normalize glucose homeostasis. In fact, islet clusters are engrafted in the periportal spaces, completely surrounded by hepatocytes and Kupffer cells (18). Therefore, the pathophysiology of insulin secretion of a system constituted by pancreatic islets and liver is evidently different from the physiological pancreatic insulin secretion. Immediately after intrahepatic injection, the islets are denervated and are vascularized by the portal vein blood. This is surely a very unfavorable condition, since $(a)$ the autonomic modulation of insulin secretion is important in maintaining an insulin secretory rate properly tuned to the glucohomeostatic needs $(17,19,20)$ and $(b)$ the portal vein blood contains high 
concentrations of metabolites of intestinal origin (i.e., glucose, lactate, amino acids) as well as a high concentration of immunosuppressive drugs (cyclosporin A, prednisone, azathioprine) administered orally, which may have a toxic effect on the $\beta$-cell function $(19,21,22)$. Re-innervation by autonomic fibers and neovascularization through the hepatic artery have been shown to take place $\sim 4-8$ wk after transplant in the rodent $(23,24)$.

Patients with functioning islets showed a near normal fasting glycemia with a blood glucose level considerably lower compared to patients without graft function. This indicates that in the best clinical and metabolic conditions islet transplant can normalize the plasma glucose concentration. This finding agrees with results obtained by transplanting the pancreas $(5-13,17)$. In $\sim 10-20 \%$ of cases, IDD patients with an intact pancreas graft experience episodic hypoglycemic symptoms $(11,12)$, and the reason for this is still under debate. To our knowledge no hypoglycemic episode was described in islet transplanted patients. The fasting plasma insulin concentration in patients after islet transplantation was approximately double that of healthy subjects (10 vs. $6 \mu \mathrm{U} / \mathrm{ml})$. The difference may be partially explained by the chronic prednisone therapy (shown to enhance insulin secretion [25]), since the group of patients with chronic uveitis (on the same dose of prednisone) also had a higher insulin level. Interestingly, the glucose/insulin ratio is not statistically different between $\mathrm{F}$ and CON in the basal state. This finding probably indicates that a new glucohomeostatic steady state has been achieved in F patients.

We showed that the basal hepatic glucose production is nearly normal in patients with functioning islet transplantation (Table IV). In contrast, the basal hepatic glucose output was significantly increased in islet transplanted patients without function. Interestingly, when the basal hepatic glucose output was correlated with the prednisone dose, a positive correlation was found $(r=0.68 ; P<0.01)$, while no correlation was found between basal hepatic glucose production and cyclosporin A $(r=-0.25 ; P=\mathrm{NS})$. These relationships indicate that prednisone is more detrimental to glucose homeostasis than cyclosporin A. Quite surprisingly, no correlation was found between the fasting hepatic glucose production and the fasting c-peptide $(r=-0.25 ; P=\mathrm{NS})$ as well as between hepatic glucose production and the number of islets transplanted $(r=$ $-0.26 ; P=\mathrm{NS})$. This indicates that factors other than the secretory capacity of the graft and the total number of islets transplanted may play a crucial role in determining the success of an islet implant. Although some patients with function were still injecting a few units of insulin daily, we are convinced that the transplanted islets had the major impact on the metabolic results. In fact, insulin therapy was withdrawn at least $36 \mathrm{~h}$ (intermediate-acting) and $18 \mathrm{~h}$ (regular) before commencement of the study.

During euglycemic hyperinsulinemia, the absolute value of hepatic glucose production was higher in NF with respect to all groups (Fig. 3). This indicates the presence of a resistance to the action of insulin at the liver site which may be caused by a variety of factors such as chronic immunosuppressive therapy, the site of transplantation, and an altered metabolic milieu. Islet transplanted patients with a functioning graft had a normal inhibition of hepatic glucose production during euglycemic hyperinsulinemia, as previously shown by us in pancreas-transplanted patients (10). In normal physiology, insulin secretion is regulated by the rise in glucose (and other substrates) concen- tration over time and the secreted insulin reaches the liver via the portal vein inhibiting the hepatic glucose output. Therefore, we raised the glucose concentration for $2 \mathrm{~h}$ in F, mimicking the glucose level after a meal $(\sim 180 \mathrm{mg} / \mathrm{dl})$. Interestingly, all islet-transplanted patients had either a defective or an absent first phase insulin release when compared with patients with chronic uveitis, healthy subjects, or pancreas-transplanted patients (Fig. 2). In addition, also the second phase insulin (but not c-peptide) release of islet transplanted patients was markedly reduced with respect to patients with chronic uveitis and healthy subjects. The discrepancy between the insulin and c-peptide response in the 20-120 min period probably reflects an insulin extraction by the liver different than that which occurs in normals. The importance of the early phase of insulin secretion in inhibiting the hepatic glucose production was previously demonstrated by us (14), as well as by other authors (26). Therefore, the altered pattern of insulin secretion of islettransplanted patients may be responsible for the post-prandial hyperglycemia which is still experienced by patients with a successful islet graft. This metabolic alteration may eventually cause a deterioration of the $\mathrm{HbA}_{1 \mathrm{c}}$ level.

To demonstrate the overall improvement of glucose homeostasis in patients with functioning graft, we showed a significantly higher tissue glucose disposal $(P<0.05)$ and metabolic clearance rate of glucose $(P<0.01)$ in this group with respect to patients without function.

In conclusion, the major metabolic advantage of the endocrine pancreas transplantation over other therapeutic modalities of treatment of IDDM is that it represents a closed-loop system, with a secretory pattern elicited by glucose and other secretagogue stimuli. Successful pancreas transplantation already has been shown to correct the metabolic abnormalities of IDDM $(5-13,19,27)$. In this work, we have demonstrated that intraportal islet transplantation (a procedure associated with a much lower morbidity) also normalizes hepatic glucose production and improves tissue glucose utilization in a selected cohort of diabetic patients.

\section{Acknowledgments}

We wish to thank Dr. Giliola Calori for her helpful suggestions for statistical analysis. This work was partially supported by H. San Raffaele, Milan, Italy, Ministero della Sanitá and Consiglio Nazionale delle Ricerche, Rome, Italy, Associazione Italiana Ricerca Cancro (AIRC), Bundesministerium für Forschung und Technologie, Bonn, Germany, FKZ 07024806, and the Juvenile Diabetes Foundation International Research Award \# 194153 (Livio Luzi).

\section{References}

1. Luzi, L., E. Barrett, L.C. Groop, E. Ferrannini, and R.A. De Fronzo. 1988. Metabolic effect of low-dose insulin therapy on glucose metabolism in diabetic ketoacidosis. Diabetes. 37:1470-1477.

2. Yki-Järvinen, H., and V. Koivisto. 1984. Continuous subcutaneous insulin infusion therapy decreases insulin resistance in Type 1 diabetes. J. Clin. Endocrinol. \& Metab. 58:659-666.

3. May, R.C., A.S. Clark, A. Goheer, and W.E. Mitch. 1985. Specific defects in insulin-mediated glucose metabolism in acute uremia. Kidney Int. 28:490497.

4. The Diabetes Control and Complications Trial Group. 1993. The effect of intensive treatment of diabetes in the development and progression of longterm complications of IDDM. N. Engl. J. Med. 329:977-986.

5. Sutherland, D.E.R., R.W.G. Gruessner, and P.F. Gores. 1994. Pancreas and islet transplantation: an update. Transplant. Rev. 8:185-206.

6. Secchi, A., J.M. Dubernard, E. La Rocca, M. Melandri, N. Lefrancois, X. Martin, J.L. Touraine, J. Traeger, and G. Pozza. 1991. Endocrino-metabolic ef- 
fects of whole vs segmental pancreas allotransplantation in diabetic patients: a two years follow up. Transplantation (Baltimore). 51:625-629.

7. Groth, G.C., H. Collste, G. Lundgren, H. Wilczek, G. Klintmalm, O. Ringden, R. Gunnarsson, and J. Östman. 1982. Successful outcome of segmental human pancreatic transplantation with enteric exocrine diversion after modification in technique. Lancet. ii:522-524.

8. Katz, H., M. Homan, J. Velosa, R.P. Robertson, and R. Rizza. 1991. Effects of pancreas transplantation on post-prandial glucose metabolism. $N$. Engl. J. Med. 325:1278-1284.

9. Elahi, D., B.A. Clark, M. McAlcon-Dyke, G. Wong, R. Brouri, M. Shapiro, K.L. Minaker, T.L. Flanagan, T. Purett, R. Gingerich, J. Hanks, and D.K. Andersen. 1991. Islet cell responses to glucose in human transplanted pancreas. Am. J. Physiol. 261:E800-E808.

10. Luzi, L., A. Secchi, F. Facchini, A. Battezzati, C. Staudacher, D. Spotti, R. Castoldi, G. Ferrari, V. Di Carlo, and G. Pozza. 1990. Reduction of insulin resistance by combined kidney-pancreas transplantation in type 1 (insulindependent) diabetic patients. Diabetologia. 33:549-556.

11. Cottrell, D.A., M.L. Henry, T.M. D’Orisio, R.J. Tesi, R.M. Ferguson, and K. Osei. 1991. Hypoglycemia after successful pancreas transplantation in Type I diabetic patients. Diabetes Care. 14:1111-1113.

12. Battezzati, A., L. Luzi, G. Perseghin, E. Bianchi, D. Spotti, A. Secchi, S. Vergani, V. Di Carlo, and G. Pozza. 1994. Persistence of counterregulatory abnormalities in insulin dependent diabetes mellitus after pancreas transplantation. Eur. J. Clin. Invest. 24:751-758.

13. Robertson, R.P. 1992. Pancreatic and islet transplantation for diabetes: cures or curiosities? N. Engl. J. Med. 327:1861-1869.

14. Luzi, L., and R.A. De Fronzo. 1989. Effect of the loss of first phase of insulin secretion on hepatic glucose production and tissue glucose disposal in humans. Am. J. Physiol. 257:E241-E246.

15. Wielko, J., and W.R. Sherman. 1976. Boroacetylation of carbohydrates. Correlations between structures and mass spectral behavior in monoacetylexoses cyclic boronic esters. J. Am. Chem. Soc. 98:7631-7637.

16. Glantz, S.A., and B.K. Slinker. 1990. Primer of Applied Regression of Analysis of Variance. McGraw Hill, Inc. New York. 1-777.

17. Luzi, L., A. Battezzati, G. Perseghin, E. Bianchi, S. Vergani, A. Secchi,
E. La Rocca, C. Staudacher, D. Spotti, G. Ferrari et al. 1992. Lack of feed-back inhibition of insulin secretion in denervated human pancreas. Diabetes. 41 1632-1639.

18. Scopsi, L., S. Andreola, C. Socci, F. Bertuzzi, V. Di Carlo, G. Pozza, F. Rilke, L. Gennari, G. Colella, E. Regalia, and V. Mazzaferro. 1994. Immunocytochemical detection and characterization of intrahepatic human pancreatic islets after combined liver-islet allotransplantation. Cell Transplant. 3:499-508.

19. Luzi, L., A. Secchi, and G. Pozza. 1992. Metabolic assessment of posttransplantation islet function in humans. Methodological considerations and possible pitfalls: a lesson from pancreas transplantation. In Pancreatic Islet Cell Transplantation. R. Ricordin, editor. Landes Co. 361-382.

20. Havel, P.J., and J.G. Taborsky 1989. The contribution of autonomic nervous system to changes of glucagon and insulin secretion during hypoglycemic stress. Endocrine Rev. 10:332-350.

21. Nielsen, J.H., T. Mandrup-Poulsen, and J. Nerup. 1986. Direct effects of cyclosporin A on human pancreatic $\beta$-cell. Diabetes. 35:1049-1052.

22. Laube, F., and H.J. Hahn. 1985. Effects of cyclosporin A on insulin secretion in vitro. Horm. Metab. Res. 17:43-44.

23. Korsgren, O., L. Jansson, A. Andersson, and F. Sundler. 1993. Reinnervation of transplanted pancreatic islet. A comparison among islet implanted into the kidney, spleen and liver. Transplantation (Baltimore). 56:1138-1143.

24. Menger, M.D., S. Jaeger, P. Walter, G. Feifel, F. Hammersen, and K. Messmer. 1989. Angiogenesis and hemodynamics of microvasculature of transplanted islet of Langerhans. Diabetes. 38:S1.

25. Hosker, J.P., M.A. Burnett, D.R. Matthews, and R.C. Turner. 1993 Prednisone enhances $\beta$-cell function independently of ambient glycemic levels in Type II diabetes. Metabolism. 42:1116-1120.

26. Mitrakou, A., D. Kelley, M. Mokan, T. Veneman, T. Pangburn, J. Reilly, and J. Gerich. 1992. Role of reduced suppression of glucose production and diminished early insulin release in impaired glucose tolerance. $N$. Engl. J. Med. 326:22-29.

27. Perseghin, G., H. Hilden, E. Bianchi, I. Terruzzi, A. Battezzati, and L. Luzi, 1993. Normal sensitivity of FFA metabolism despite resistance of glucose metabolism to insulin after pancreas transplantation. Diabetes. 43(S2): $138 a$ 